\title{
Bullous arthropod bite reaction
}

\author{
Philip Collins, Jennifer Sepede
}

Family Medicine, Rowan University School of Osteopathic Medicine, Stratford, New Jersey, USA

\section{Correspondence to Dr Philip Collins, collinsp@rowan.edu}

Accepted 1 November 2018

\section{DESCRIPTION}

A 61-year-old woman with a medical history of hypothyroidism presented to the office with blistering skin lesions on bilateral lower legs (figure 1). The lesions first appeared about 5 days prior to her office visit. The patient stated she was bitten multiple times by what she believes were greenhead flies. The blisters then began to develop the following day. The lesions were painful and somewhat pruritic. She noted only one other reaction to bug bites like this in the past, about 1 year ago, but says it was not as severe. The patient went to urgent care 4 days prior to the office visit and was given minocycline. Physical exam revealed multiple bullous lesions on the medial/posterior surface of bilateral lower legs.

The patient was treated with a tapering course of oral corticosteroids and instructed on proper wound care with soap and water. She was seen again in the office 2 weeks later with good resolution of her lesions. The patient also had subsequent lab testing which revealed an unremarkable complete blood count. HIV testing was negative.

Insect bites produce an inflammatory or allergic reaction with variable response. Reactions can vary from no reaction to pruritic papules, vesicles or even bullae in some cases. It is thought that the saliva from the bite of the organism serves as an allergen. When there is only limited allergen exposure, the response is typically mild, but when the antigen exposure is

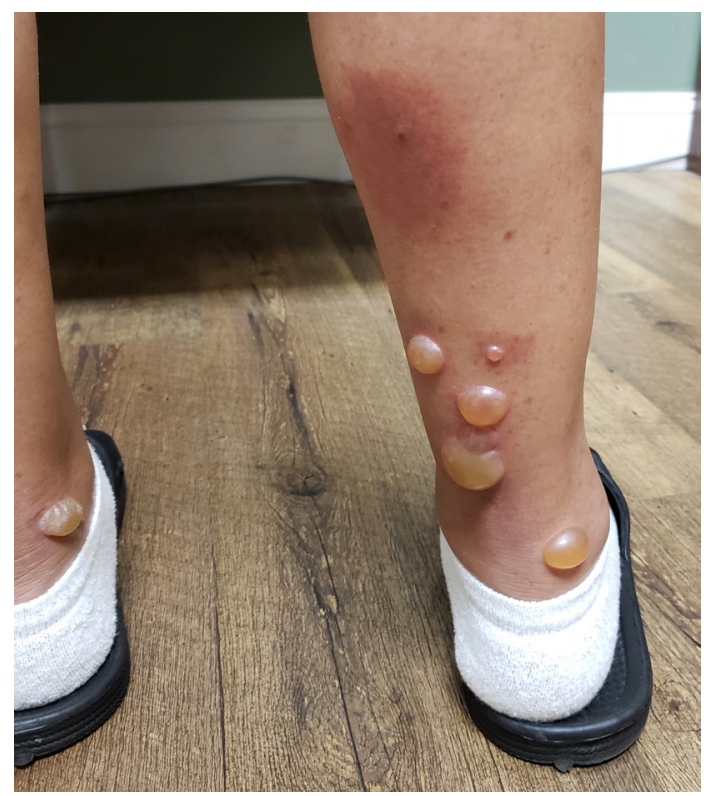

Figure 1 Bullous skin lesions on bilateral lower legs. more considerable a vesiculobullous reaction can occur. ${ }^{1}$ Bullous-type reaction, or bullous arthropod bite reaction, is a delayed response hypersensitivity reaction occurring in sensitised individuals. The occurrence of a bullous reaction can be common in patients with chronic lymphocytic leukaemia and other haematological cancers. ${ }^{2}$ Insect bites should be washed with soap and water to prevent secondary infection. Topical steroids and antihistamines are helpful to manage pruritus. ${ }^{3}$

\section{Patient's perspective}

When the bites first occurred I thought I was having an allergic reaction, but the next morning I woke up with blisters on my legs. I became concerned because of how painful they were, especially first thing in the morning. The blisters were so big. Once I started my prescription I knew I was getting better. Now I just worry that my next reaction could be worse.

\section{Learning points}

Bullous reactions to insect bites are not uncommon.

- Bullous reactions to insect bites can be treated with steroids and patients should be counselled on prognosis.

- Consider leukaemia and other haematological cancers in patients with bullous reactions as these reactions are more common in patients with these disorders.

Contributors PC and JS: managed the case, performed the literature search and drafted the manuscript.

Funding The authors have not declared a specific grant for this research from any funding agency in the public, commercial or not-for-profit sectors.

Competing interests None declared.

Patient consent Obtained.

Provenance and peer review Not commissioned; externally peer reviewed.

\section{REFERENCES}

1 Fitzpatrick JE, High WA, Kyle WL. Urgent care dermatology: symptombased diagnosis. Philadelphia: Elsevier, 2018.

2 Morrell DS, Brooks K, Tintinalli JE, et al. Skin disorders: trunk. Tintinalli's emergency medicine: a comprehensive study guide. 8edn. New York, NY: McGraw-Hill, 2016.

3 Schwartz RA, Steen CJ. et a/Chapter 210. Arthropod bites and stings. In: Goldsmith LA, Katz SI, Gilchrest BA, Paller AS, Leffell DJ, Wolff K, eds. Fitzpatrick's dermatology in general medicine. 8 edn. New York, NY: McGraw-Hill, 2012 
Copyright 2018 BMJ Publishing Group. All rights reserved. For permission to reuse any of this content visit https://www.bmj.com/company/products-services/rights-and-licensing/permissions/

BMJ Case Report Fellows may re-use this article for personal use and teaching without any further permission.

Become a Fellow of BMJ Case Reports today and you can:

- Submit as many cases as you like

- Enjoy fast sympathetic peer review and rapid publication of accepted articles

Access all the published articles

- Re-use any of the published material for personal use and teaching without further permission

For information on Institutional Fellowships contact consortiasales@bmjgroup.com

Visit casereports.bmj.com for more articles like this and to become a Fellow 